\title{
Fertility Lifetables of Glasshouse Whitefly Trialeurodes vaporariorum (Westwood) on French Bean cv. Contender at Different Temperatures
}

\author{
Jyoti Kapil ${ }^{* *}$ and Manica Tomar ${ }^{2}$ \\ ${ }^{1}$ Dept. of Biotechnology, Kanoria P.G Mahila Mahavidyalaya, Jaipur, Rajasthan (302 004), India \\ ${ }^{2}$ Directorate of Extension Education, Dr. Yashwant Singh Parmar University of Horticulture and Forestry, Nauni, Solan, Himachal \\ Pradesh (173 230), India
}

Corresponding Author

Jyoti Kapil

e-mail: jyotikapil31@gmail.com

\author{
Article History \\ Article ID: IJEP0356 \\ Received in $02^{\text {nd }}$ January, 2020 \\ Received in revised form $18^{\text {th }}$ January, 2020 \\ Accepted in final form $29^{\text {th }}$ January, 2020
}

\section{Abstract}

Fertility Life tables and characteristics of the Trialeurodes vaporariorum (Westwood) were assessed on French bean cv. Contender at different temperatures $15,20,25$ and $30^{\circ} \mathrm{C}$. The life table analysis showed that the females lived for a maximum of 58 days at $15{ }^{\circ} \mathrm{C}$. The trend of oviposition showed a peak on $32^{\text {nd }}$ day at $25^{\circ} \mathrm{C}$ as the highest number of eggs produced per female per day was 9.98 . The true Intrinsic rate of increase $\left(r_{m}\right)$ values were 0.123 and 0.121 at $20^{\circ} \mathrm{C}$ and $25^{\circ} \mathrm{C}$, respectively. The rate of natural increase $\left(r_{c}\right)$ was 0.120 at $20{ }^{\circ} \mathrm{C}$ and 25 ${ }^{\circ} \mathrm{C}$. The highest net reproductive rate $(45.86)$ was obtained at $20^{\circ} \mathrm{C}$. The population doubling time (DT) was maximum $\left(10.42\right.$ days) at $15^{\circ} \mathrm{C}$ and minimum (5.64 days) at $20^{\circ} \mathrm{C}$. Generation time was 47.17 days at $15^{\circ} \mathrm{C}$ which decreased to 24.82 days at $30{ }^{\circ} \mathrm{C}$.

Keywords: Life-fertility Table, Trialeurodes vaporariorum, French beans

\section{Introduction}

Vegetables constitute an essential component of a balanced diet and play a vital role in the maintenance of good human health. Pest infestation and related diseases are major constraints in vegetable production. The warm temperature of spring and summer brings a flush of new foliage growth which attracts a wide variety of pestslike sap suckers foremost being whiteflies which can cause serious damage to crops worldwide (Peric, 1994).

The whiteflyis an important insect pest on a global scale, attacking a wide variety of agricultural commodities especially in vegetable and ornamental crops including citrus, squash, poinsettia, potato, cucumber, grape, tomato, hibiscus etc. (Van Lenteren and Martin, 2000). Trialeurodes vaporariorum (Westwood) commonly known as glasshouse whiteflyis a polyphagous pest. It was first described as Aleurodes vaporariorum (Westwood, 1856) from whiteflies collected from tomato in glasshouses throughout Europe (Quaintance, 1900). In India, it was reported at Thumantty (Nilgiris) infesting potatoes (David, 1971). The nymphs and adults suck the vital sap from the foliage which reduces photosynthetic activity of the plants (Yamada et al., 1979). The damage is inflicted by yellowing of leaves which later fade and dry away (Baker, 1922). The honeydew secreted by nymphs and adults of whitefly results in sooty mould which makes plants unsightly and valueless (Garman and Jewett, 1992; Johnson et al., 1992; Omar et al., 1992; Liu et al., 1993) and also reduces photosynthetic activity of the plants (Yamada et al., 1979; Tosh and Brogan, 2015).

Although whiteflies themselves can cause significant crop damage, $T$. vaporariorum-vectored viruses can cause losses that are much more economically damaging than those resulting from vector feeding alone (Byme et al., 1990). The viruses have been found to be transmitted by Trialeurodes, all within the genus Crinivirus (Wisler et al., 1998; Wisler and Duffus, 2001).

The whitefly species like Bemisia tabaci (Gannadius) and $T$. vaporariorum are serious pests of large cultivated crops throughout the world and in India, it poses potential threat to the cultivation of highly remunerative crops like tomatoes, beans and cucurbits. Since French bean is a short duration (85-90 days) crop, it fits as a component of intercropping and sequence cropping in many of the agro-climatic zones.In India, French bean is cultivated in 137.54 thousand hectare with production of 1370.21 thousand tones and productivity of 478 $\mathrm{kg} \mathrm{ha}^{-1}$ (Saxena et al., 2015). The pests that attack French beans at different growth stages include white flies, pod borers and leaf miners (Lohr, 2006). Since, the construction of life 
fertility tables is vital for determining the inherent capacity of an insect to increase in numbers and understanding population dynamics of a species (Phadke,1982). Hence, keeping in view the serious nature of the pest and potential threat it poses to the cultivation of highly remunerative crops like tomatoes, beans and cucurbits, an attempt was made in the present study to critically assess the reproductive potential of $T$. vaporariorum on French bean cV. Contender. The calculation of growth rate statistics is, therefore, a value for determining the growth potential of whitefly population under a given set of environmental conditions. The present study will enable us to know their potential in different temperature conditions.

\section{Materials and Methods}

All experiments were conducted at the Department of Entomology, Dr. Yashwant Singh Parmar University of Horticulture and Forestry, Nauni, Solan, Himachal Pradesh in climatic chambers operating under controlled conditions (15, 20,25 and $30^{\circ} \mathrm{C}$ ). The culture of whitefly was raised in the laboratory on French bean cv. Contender. The French bean seedlings were grown in disposable cups and after 6-7 days of emergence, transferred to rearing cages $\left(40 \times 30 \times 40 \mathrm{~cm}^{3}\right)$. The adults were released on the seedlings. The pots were taken out and leaves were observed under the microscope for egg laying activity of the insects.

After egg laying, the eggs were marked withpointed tip permanent Faber castle make markers, then the seedlings were taken out and covered with glass chimney $(20 \times 15$ $\mathrm{cm}^{2}$ ). The top of the chimney was covered with muslin cloth. The effect of temperature on the development of whitefly was studied in BOD incubators maintained at four constant temperatures i.e.15, $20,25,30{ }^{\circ} \mathrm{C}$. A photoperiod of $14: 10$ (L:D) and relative humidity of $70 \%$ maintained at all the temperatures and replicated ten times. Daily observations at all temperatures were taken. The age specific survival $\left(I_{x}\right)$ and age specific fecundity $\left(m_{x}\right)$ at each pivotal age $(x)$ were worked out daily for entire reproductive period to prepare fertility table as per the details given by Andrewartha and Birch (1954) and Southwood (1978).

Life table was constructed using the following column of parameters:

$X$ : the pivotal of individuals (days)

$I_{x}$ : the number of surviving individuals at age $X$

$m_{x}$ : the number of living females born per female in age interval $X($ fecundity rate)

The reproduction rate: $G R R=\Sigma m_{x}$

Net reproduction rate of increase: $R_{0}=\Sigma I_{x} m_{x}$ Approximate generation time (in days) $T_{c}=\sum X I_{x} m_{x} / R_{o}$ True generation time (in days): $T=\log _{e} R_{o} / r_{x}$ The innate capacity for increase: $r_{c}=\log _{e} R_{o} / T_{c}$
True Intrinsic rate of increase: $r_{m}=\sum e_{m}^{7-r} x I_{x} m_{x}$ Finite rate of increase: $\lambda=$ antilog $_{\mathrm{e}} r_{\mathrm{m}}$ Population doubling time: $D T=\log _{e} 2 / r_{m}$ Weekly multiplication rate: $W M=$ antilog $_{e} r_{m}{ }^{7}$

\section{Results and Discussion}

The age specific survival and age specific fecundity is illustrated graphically (Figure 1-4), the perusal of which revealed reproductive potential of $T$. vaporariorum at different temperatures. The whitefly had a maximumlife span of 58 days at $15{ }^{\circ} \mathrm{C}$ and pre-oviposition period was of 39 days. The oviposition started on $43^{\text {rd }}$ day and maximum fecundity (6.80) was on $49^{\text {th }}$ day (Figure 1 ). At $20^{\circ} \mathrm{C}$, lifespan was 42 days of which immature stage occupied 24 days. The oviposition started on $27^{\text {th }}$ day and maximum age specific fecundity (9.66) was attained on $34^{\text {th }}$ day, respectively (Figure 2).The fertility statistics at $25{ }^{\circ} \mathrm{C}$ revealed that oviposition lasted for 15 days and female contributed highest egg production (9.98) on $7^{\text {th }}$ day of oviposition. The egg laying ceased on $41^{\text {st }}$ day of pivotal age (Figure 3). At $30^{\circ} \mathrm{C}$, the total lifespan of $T$. vaporariorum was 32 days and immature stages lasted for 20 days. The oviposition started on $22^{\text {nd }}$ day and lasted for 8 days, the maximum fecundity (4.35) was on $25^{\text {th }}$ day (Figure 4). At all temperatures, the mortality mostly acts heavily on old individuals and was almost constant with time. Works done by

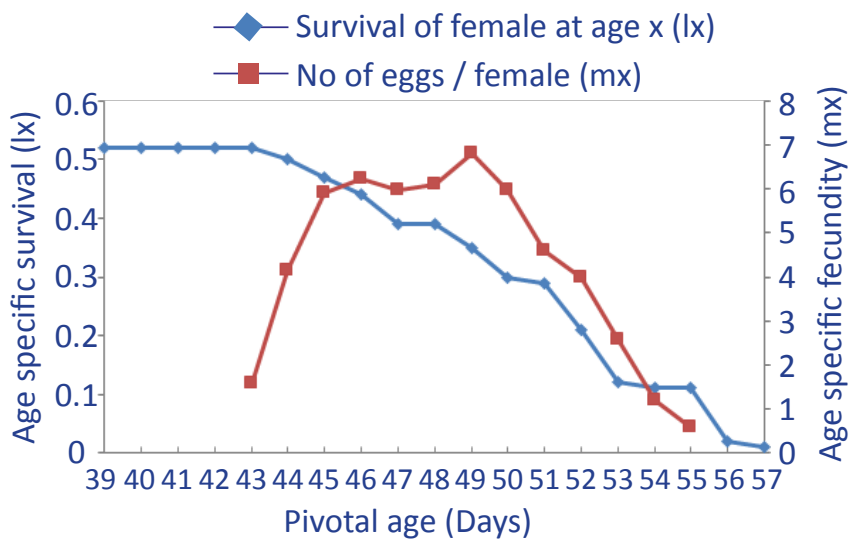

Figure 1: Daily age specific survival and age specific fecundity of $T$. vaporariorum on French beans cv. Contender at $15 \pm 1^{\circ} \mathrm{C}$

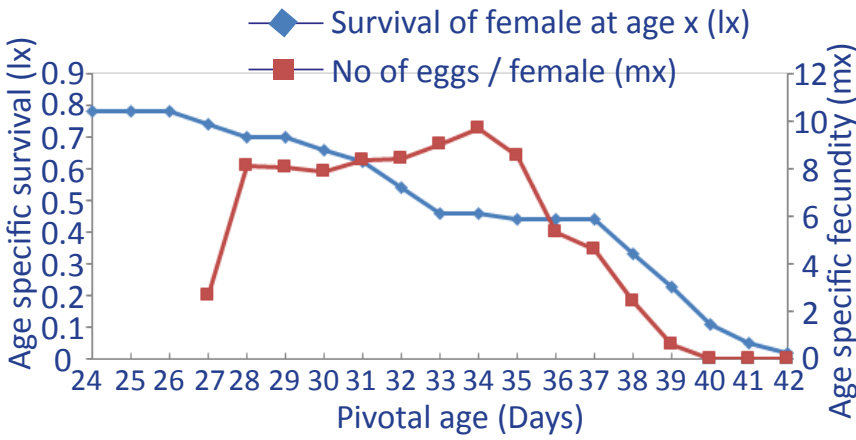

Figure 2: Daily age specific survival and age specific fecundity of $T$. vaporariorum on French beans cv. Contender at $20 \pm 1^{\circ} \mathrm{C}$ 


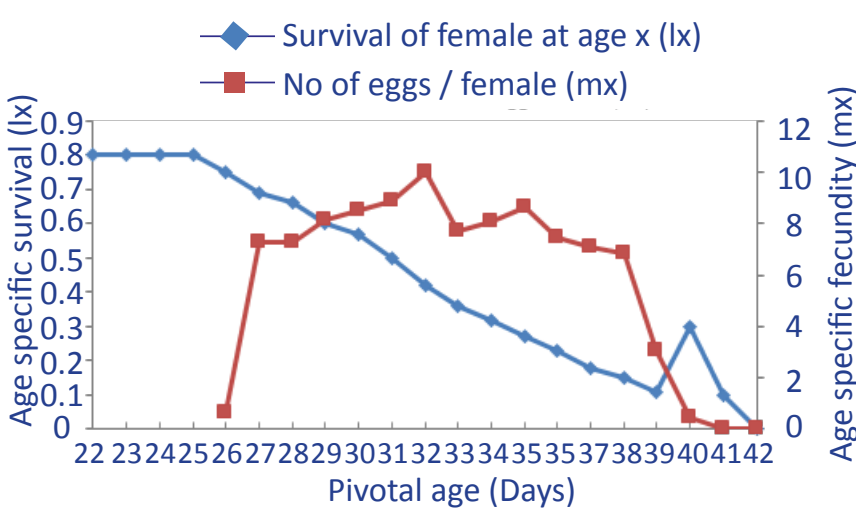

Figure 3: Daily age specific survival and age specific fecundity of $T$. vaporariorumon French beans cv. Contender at $25 \pm 1{ }^{\circ} \mathrm{C}$

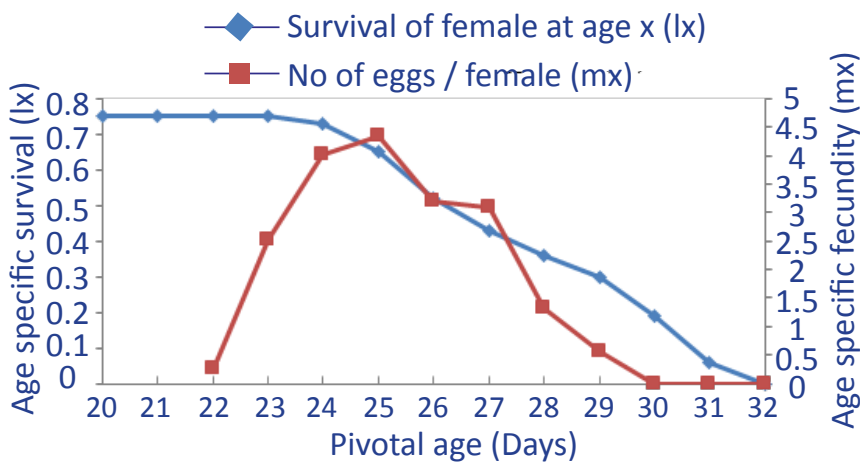

Figure 4: Daily age specific survival and age specific fecundity of $T$. vaporariorum on French beans cv. Contender at $30 \pm 1{ }^{\circ} \mathrm{C}$

Verma et al. (1990) are in consonance with the present work.

Fertility table statistics of $T$. vaporariorum on French bean at different temperatures presented in Table 1 revealed that the higher net reproductive rate $\left(R_{0}\right)$ was at $20^{\circ} \mathrm{C}$ and $25{ }^{\circ} \mathrm{C}$. The temperature below $20{ }^{\circ} \mathrm{C}$ and above $25{ }^{\circ} \mathrm{C}$ decreases the whitefly population. Rodriguez et al. (2005) made a generalization regarding climatic conditions that T.vaporariorum is absent in the area where $\mathrm{RH}$ is higher than $80 \%$ but other whitefly species like Bemisia tabaci (Gennadius) biotype B are present on vegetable crops.

This observation is supported by findings of Burnett (1949) who reported the maximum fecundity between 18 and 21 ${ }^{\circ} \mathrm{C}$ and maximum female longevity at $15^{\circ} \mathrm{C}$ with very short survival at $9^{\circ} \mathrm{C}$ and temperatures over $27^{\circ} \mathrm{C}$. These results are corroborated by the work done byVerma et al. who studied the life cycle of the whitefly and concluded that temperature ranges from 23 to $30{ }^{\circ} \mathrm{C}$ provided optimal conditions for development of $T$. vaporariorum .

The gross reproductive rate (GRR) of $T$. vaporariorum was $55.71,87.69,100.22$ and 19.34 while net reproductive rate was 19.99, 45.86, 40.83 and 11.50 at 15, 20, 25 and $30{ }^{\circ} \mathrm{C}$, respectively. The difference in gross and net reproductive rate may be attributed to mortality of the parent female before reaching the maximum reproductive age at the respective temperature. The whitefly completed one generation $\left(T_{c}\right)$ in 34.78 days at $15^{\circ} \mathrm{C}, 31.66$ days at $20^{\circ} \mathrm{C}, 31.03$ days at 25 ${ }^{\circ} \mathrm{C}$ and 24.90 days at $30{ }^{\circ} \mathrm{C}$. The temperature was inversely proportional to duration of development. Yano (1988) while working on survival rate of $T$. vaporariorum adults also found that at low temperatures the survival capacity of the fly reduced considerably.

The innate capacity of natural increase $\left(r_{c}\right)$ gives the actual rate of a species with no overlapping of generation and is derived from survival rate and reproductive performance of a cohort of females. It was found that the $r_{c}$ was maximum $(0.120)$ at 20 and $25^{\circ} \mathrm{C}$. This was attributed to the fact that the intrinsic rate of increase $\left(r_{m}\right)$ gives response of an organism to a particular set of environmental conditions and therefore, it gives a precise estimate of the reproductive capacity of a species (Birch, 1948; Bursell, 1964; Macfadyan, 1963 and Messanger, 1964). It was observed that maximum $r_{m}$ value (0.123) was at $20^{\circ} \mathrm{C}$ and the nearly same value of $r_{m}(0.121)$ was at $25^{\circ} \mathrm{C}$. Calvitti and Buttarazzi (1995) also reported the similar $r_{m}$ value (0.121) of T. vaporariorum population on marrows.

The higher rate of finite increase $(\lambda)$ was 1.13 per female per day at 20 and $25^{\circ} \mathrm{C}$. The population multiplied weekly 1.57 ,

Table 1: Fertility table statistics of T. vaporariorumon French beancv. Contender at different temperatures.

\begin{tabular}{lcccccccccc}
\hline $\begin{array}{l}\text { Tempera- } \\
\text { ture }\left( \pm{ }^{\circ} \mathrm{C}\right)\end{array}$ & $\mathrm{G}$ GR & $\mathrm{R}_{\mathrm{o}}$ & $\mathrm{T}_{\mathrm{c}}$ & $\mathrm{r}_{\mathrm{c}}$ & $\mathrm{r}_{\mathrm{m}}$ & $\mathrm{T}$ & $\lambda$ & $\mathrm{WM}$ & $\mathrm{DT}$ \\
\cline { 2 - 9 } 15 & 55.71 & 19.99 & 34.78 & 0.086 & 0.064 & 47.17 & 1.07 & 1.57 & 10.83 \\
20 & 89.69 & 45.86 & 31.66 & 0.120 & 0.123 & 31.10 & 1.13 & 2.37 & 5.64 \\
25 & 100.22 & 40.83 & 31.03 & 0.120 & 0.121 & 30.60 & 1.32 & 2.33 & 5.73 \\
30 & 19.34 & 11.50 & 24.90 & 0.098 & 0.098 & 24.82 & 1.10 & 1.99 & 7.04 \\
\hline
\end{tabular}

$2.31,2.33$ and 1.99 times at $15,20,25$ and $30^{\circ} \mathrm{C}$, respectively and doubling time was maximum at $15^{\circ} \mathrm{C}(10.83)$ and minimum (5.64) at $20^{\circ} \mathrm{C}$. No such work appears to have been carried out at constant temperature. However, Yano( 1989) studied the effect of two temperature regimes 24 and $30^{\circ} \mathrm{C}$ during the day time and 10 and $25^{\circ} \mathrm{C}$ during night on population growth of $T$. vaporariorum on tomato and concluded that low temperature regimes decreased survival rate of eggs and larva and the higher temperature increase the intrinsic rate of natural increase. Yano (1988) also found that survival rate of $T$. vaporariorum adults reduced at low temperature. Recently, it was found that $T$. vaporariorum possesses less tolerance to higher temperatures than B. tabaci biotype $B$, probably linked to the expression of heat shock protein genes 
(Wan et al., 2009).

\section{Conclusion}

This study provides important data for understanding the population dynamics of $T$. vaporariorum, for development of potential population dynamic models and pest forecasting. Further, the whitefly population growth model can be used to evaluate effects of intended changes in the cropping system, e.g., of changes in climate and crop species or cultivar on whitefly development. Result of this study indicated that optimum temperature for population growth of $T$. vaporariorum was between 20 to $25^{\circ} \mathrm{C}$, so early sowing of French bean can help the crop escape the onslaught of this pest.

\section{References}

Andrewartha, G.H., Birch, L.C., 1954. The distribution and abundance of animals. University of Chicago Press, Chicago, 782.

Baker, A.C., 1922. Feeding punctures of insects. Journal of Economic Entomology 15, 312.

Birch, L.C., 1948. The intrinsic rate of natural increase in an insect population. Journal of Animal Ecology 17, 15-26.

Burnett, T., 1949. The effect of temperature on an insect hostparasite population. Ecology 30, 113-134.

Bursell, E., 1964. Environmental aspects: temperature. In: the physiology of insects. Vol. I. (Rockstein, M. ed.). Academic Press, 281-361.

Byme, D.N., Bellows, T.S., Parrella, M.P., 1990. Whiteflies in agricultural systems. Ingerling, D. (Ed.), Whiteflies: their bionomics,pest status and management. Intercept. Andover, UK, 227-261.

Calvitti, M.,Buttarazzi, M., 1995. Determination of biological and demographic parameters of Trialeurodes vaporariorum Westwood on two host plant species Zucchini (Cucurbita pepo) and Tomato (Lycopersicon esculentum). Redia 78, 29-37.

David, B.Y., 1971. Studies on South Indian Aleyrodidae. Doctoral Thesis, Tamil Nadu Agricultural University. Coimbatore.

Garman, H., Jewett, H.H., 1922. The whiteflies of hot-houses. Kentucky Agriculture Experimental Station Bulletin, 76-111.

Johnson, M.W., Caprio, L.C., Coughli, J.A., Rosenheim, J.A., Welter S.C., 1992. Effect of Trialeurodes vaporariorum (Homoptera: Aleyrodidae) on yield of French market tomatoes. Journal of Economic Entomology 85, 23702376.

Liu, T.X., Oetting, R.D., Buntin, G.D., 1993. Population dynamics and distribution of Trialeurodes vaporariorum and Bemisia tabaci (Homoptera: Aleyrodidae) on poinsettia following applications of three chemical insecticides. Journal of Entomological Science 28, 126-135.

Lohr, B., 2006. High value crops research and development: the ICIPE experience. International Centre of Insect Physiology and Ecology, Nairobi, Kenya.

Macfadyan, A., 1963. Animal Ecology: aims and methods. Pitman and Sons London, 344.

Messanger, P.S., 1964. Use of life tables in bioclimatic study of an experimental aphid, braconid wasp host parasite system. Ecology 45, 119-131.

Omar, A.D., Leigh, T.F., Granett, J., 1992. Insecticide resistance in populations of greenhouse whitefly (Homoptera: Aleyrodidae) in the San Joaquin valley (California) cotton system. Journal of Economic Entomology 85, 21-27.

Peric, P., 1994. Relationship of Trialeurodes vaporariorum Westwood and parasitoid Encarsia formosa Gahan (Hym: Aphelinidae). Zashchita Rostenii 49, 215-220.

Phadke, K.G., 1982. Life table and growth rate studies on Lipaphis erysimi in relation to Brassica varieties. Indian Journal of Entomology 44, 136-144.

Quaintance, A.L., 1900. Contributions toward a monograph of the American Aleurodidae.Bulletin of the UnitedStates Department of Agriculture Entomology Technician 8, 9-43.

Rodriguez, I., Cardona, C., Morales, H., Bueno, J.M., 2005. El biotipo B de Bemisia tabaci (Gennadius) (Homoptera: Aleyrodidae) adquiere mayor importancia en el Valle del Cauca. The Revista Colombiana de Entomologia 31, 21-28.

Saxena, M., Bhatacharya, S., Malhotra, S.K., 2015. Horticulture Statistics at a Glance, Oxford University Press, New Delhi.

Southwood, T.R.E., 1978. Ecological methods with particular reference to the study of insect populations, $2^{\text {nd }}$ ed. London: Chapman and Hall.

Tosh, C.R., Brogan, B., 2015. Control of tomato whiteflies using the confusion effect of plant odours. Agronomy for Sustainable Development 35, 183-193.

Van Lenteren, J.C., Martin, N.A., 2000.Biological control of whiteflies.In :Albajes, R., Gullino, M., Van Lenteren, J.C., Elad, Y. (Eds), Integrated pest and disease management in greenhousecrops. Dordrecht, Kluwer Publishers, 202-214.

Verma, A.K., Ghatak, S.S., Mukhopadhyay, S., 1990. Effect of temperature on development of whitefly (Bemisia tabaci) (Homoptera: Aleyrodidae) in West Bengal. Indian Journal of Agricultural Sciences 60, 322-326.

Wan, F., Zhang, G., Liu, S., Luo, C., Chu, D., Zhang, Y., Zang, L., Jiu, M., La, Z., Cui, X., Zhang, L., Zhang, F., Zhang, Q., Liu, W., Liang, P., Lei, Z., Zhang, Y., 2009. Invasive mechanism and management strategy of Bemisia tabaci (Gennadius) biotype B: Progress report of 973 Program on invasive alien species in China. Science in China Series C-Life Sciences 52, 88-95.

Westwood, J.O., 1856. A new Aleyrodes of the greenhouse. Gardeners Chronicle, 852.

Wisler, G.C., Duffus, J.E., 2001. Transmission properties of whitefly-borne Criniviruses and their impact on virus 
epidemiology. In: Virus-Insect-Plant Interactions. Academic Press, 293-308.

Wisler, G.C., Li, R.H., Liu, H.Y., Lowry, D.S., Duffus, J.E., 1998. Tomato chlorosis virus: a new whitefly-transmitted, phloem-limited, bipartite closterovirus of tomato. Phytopathology $88,402-$ 409.

Yamada, H., Koshihara, T., Tanaka, K., 1979. Population growth of the greenhouse whitefly Trialeurodes vaporariorum on greenhouse cucumber. Bulletin of Vegetable and Ornamental Crops Research Station, Japan 5, 191-199.
Yano, E., 1988. The population dynamics of the greenhouse whitefly (Trialeurodes vaporariorum) and the parasitoid Encarsia formosa Gahan. Bulletin of the National Research Institute of Vegetables, Ornamental Plants and Tea, Japan, 143-200.

Yano, E., 1989. Factors affecting population growth of the Trialeurodes (Hemiptera: Aleyrodidae). Japanese Journal of Applied Entomology and Zoology 33, 122-127. 